\title{
THE EFFECT OF APPLYING E-SPT, E-INVOICING AND E-FILING AGAINST TAXPAYER COMPLIANCE ON THE EAST DENPASAR PRATAMA TAX SERVICE OFFICE
}

\author{
I Made Dwi Adnyana ${ }^{1 *}$. Anik Yuesti ${ }^{2}$ \\ 1,2Economics and Business Faculty University of Mahasaraswati Denpasar \\ Bali, Indonesia 80361
}

*Corresponding Author email: mdwiadnyana@unmas.ac.id

\begin{abstract}
The reporting system's Application using e-SPT, e-Invoice, and e-Filing can help taxpayers report their tax returns 24 hours for seven days. This means that taxpayers can report their tax returns even on holidays. The purpose of this study was to examine and obtain empirical evidence of the influence of the Application of e-SPT, the Application of e-Invoicing, and the Application of e-Filing to taxpayer compliance at the East Denpasar Pratama Tax Office in 2018. The samples used in this study were 100 obtained based on the sampling technique incidental. The data analysis technique used in this study is the multiple linear regression analysis. This study's results indicate that the Application of e-SPT, Application of e-Invoicing, and e-Filing positive effect on taxpayer compliance at the East Denpasar Pratama Tax Office.
\end{abstract}

\author{
Article History \\ Submission: July 19, 2020 \\ Revised: August 28, 2020 \\ Accepted: September 20, 2020 \\ Keywords: \\ Application of e-SPT, \\ Application of e-Invoice, \\ Application of e-Filing, \\ Taxpayer Compliance. \\ Abbreviations: NIL \\ do \\ 10.31580/jmi.v7i3.1548
}

\section{INTRODUCTION}

Tax is one of the highest incomes in Indonesia. The Tax is used to improve and facilitate public facilities and for the welfare of the community. Thus, the Government has always sought to increase revenue from the tax sector to eradicate the tax mafia and improve the tax collection system. The taxpayer's role in taxes can be felt directly or indirectly in daily life. The Tax's perceived benefits are educational facilities, transportation facilities, health facilities, and public infrastructure (Agustiningsih, 2016).

Through the Directorate General of Tax (DGT), the government continues to implement breakthroughs to optimize tax revenue through policies issued. One of the steps taken by the Directorate General of Taxes is to carry out tax reforms. The East Denpasar Pratama Tax Service Office was chosen as a research location because the KPP has implemented a modern tax administration system. Besides this, the Compliance of Taxpayers (Non-Taxable Entrepreneurs and Taxable Entrepreneurs) at the research location in East Denpasar KPP experienced fluctuations in the 2015-2018 period. The instability that occurs at the level of taxpayer compliance becomes the

\section{Readers /nsight}


reason researchers re-examine the factors that influence taxpayer compliance at East Denpasar KPP.

Table 1. Level of Taxpayer Compliance (Non-PKP and PKP) in East Denpasar STO. (The year 20152018)

\begin{tabular}{ccccc}
\hline Year & Number of Registered TP & No. TP Effective/ Active & TP Delivering SPT & Compliance\% \\
\hline 2015 & 95459 & 90686 & 46857 & $51.67 \%$ \\
2015 & 95.459 & 90.686 & 46.857 & $51,67 \%$ \\
2016 & 100.220 & 93.205 & 53.648 & $57,56 \%$ \\
2017 & 105.252 & 99.989 & 54.364 & $54,37 \%$ \\
\hline
\end{tabular}

Source: East Denpasar KPP Pratama 2019

Based on table 1 above, it can be seen that the number of non PKP and PKP taxpayers registered from 2015 to 2018 continues to increase, while the level of Compliance has fluctuated. Until 2018 the East Denpasar Pratama Tax Office recorded 109,893 registered taxpayers, but only 59,987 taxpayers submitted tax returns. This shows that taxpayers' level of Compliance in the East Denpasar Pratama Tax Office is still low, only 55.14\%. Taxpayer compliance is influenced by two factors of internal factors and external factors. Internal factors originate from within the Taxpayer and relate with individual characteristics that are the triggers in carrying out their tax obligations. In contrast to external factors are factors originating from outside the Taxpayer themselves, such as the situation and the environment around Taxpayers (Prabawa and Noviari, 2012). The increase in tax revenue is inseparable from the tax amnesty policy.

The Directorate General of Taxes tries to provide excellent service to taxpayers and make innovations in their services. One of the innovations carried out by the Directorate General of Taxes is to utilize technology by carrying out tax reforms that produce tax e-systems that include e-SPT, e-invoicing, and e-filing. Thus it will be easier for taxpayers to report Notification.

Modernization of the tax reporting system has been carried out since January 24, 2005. The application e-SPT or Electronic SPT is an application for creating electronic notification forms. e-SPT is made to replace paper form notification forms, the Application of this Application minimizes waste of paper usage. e-SPT which is applied now is a computer application to submit SPT. e-SPT provided includes the ereturn period and annual. The application e-Invoice is a method provided by DGT in terms of making electronic tax invoices. In addition to making tax invoices, this eInvoice is also used to report VAT Period Tax Returns for companies that already have a decision letter as a Taxable Entrepreneur. The application e-Filing is one of the SPT reporting in electronic form which is done on the DJP Online website. the purpose for which it is applied e-Filing, which is for ease of reporting Notification (SPT).

The existence of a reporting system using e-SPT, e-Invoice, and e-Filing can make it easier for taxpayers to report their tax returns 24 hours for 7 days. This means that taxpayers can report their tax returns even on holidays. This system is beneficial for 
taxpayers who do not report their tax returns on busy grounds. Besides, the existence of e-SPT, e-Invoice, and e-Filing can reduce costs arising from the use of paper. However, the fact is that there are still many taxpayers who do not fully understand how to report their tax returns electronically.

Reporting Notification (SPT) is one of the taxpayers' obligations as mandated by the Indonesian Taxation Law.

Research conducted by Harish, (2014), Indrianti, (2017) which shows that there is a positive and significant influence on the implementation of the system e-SPT on compulsory compliance Agency tax The results of research conducted by Husnurrosyidah, (2017), Indrianti, (2017), , show that e-invoicing has a positive and significant effect on tax compliance. Research conducted by Havid, (2014), Suherman, (2016), Husnurrosyidah, (2017), Indrianti, (2017), Maryani, (2019), and Pratama, (2019) indicates that e-filing a positive and significant effect on taxpayer compliance. This shows the better system e-filing resulting in tax compliance will also increase. Meanwhile, according to researchers Indrianti (2017) shows that e-filing does not affect tax compliance. This is because not all taxpayers to use e-filing. After all, taxpayers still consider that the use of computerized systems in the delivery of SPT is very confusing and complicated.

Based on the description above, the authors are interested in conducting research and studies on "The Effect of Applying e-SPT, e-invoicing, and e-Filing Against Taxpayer Compliance at the East Denpasar Pratama Tax Service Office".

\section{LITERATURE REVIEW}

\section{THEORY OF TECHNOLOGY ACCEPTANCE MODEL (TAM)}

Davis first developed Technology Acceptance Model (TAM) in 1989. The Technology Acceptance Model (TAM) predicts and describes how technology users accept and use technology related to work or user tasks. In this theory, users' acceptance or users of information technology becomes an important part of the research. Before it is used and known for its success, it is first confirmed about the acceptance or rejection of technology users' use of information technology. User acceptance of information technology is a factor in the use and utilization of information systems developed.

The acceptance of information technology users is closely related to various user problems and the potential to be accepted if information technology is applied in user activities related to taxation activities. TAM assumes there are two paramount behavioral variables confidence in adopting an information system. The first factor is the perception of the usefulness (Perceived usefulness). The second factor is the perceived ease in the use of technology (Perceived ease of use). Perceived usefulness is defined as the level where someone believes that the Application of a particular system can improve performance in carrying out the task. Perceived ease of use is defined as when someone believes that no effort is needed (free of effort) in using the 
system. Perceived ease of use also affects the perceived usefulness which can be interpreted that if someone feels that the system is easy to use, the system is useful for them in completing the task of

Utilization and ease of use of technology will affect the interest to use it and subsequently form a value plus. The Technology Acceptance Model (TAM) in this study is used as the basis that perceptions of usefulness and perceived ease of use of information technology affect individual behavior towards the use of information technology, further determining whether individuals intend to use information technology. The technology in question is an e-SPT, e-invoicing, and e-filing system.

This study measures the variable implementation of e-SPT, Application of e-Invoicing, and Application of e-filing to taxpayer compliance. A taxpayer who is obedient and obedient in carrying out his obligation to pay taxes is a direct role for state financing and national development, Tax is also one of the biggest contributors to state revenue. In general, Tax is a mandatory contribution to a country that is owned by a Taxpayer that is forced and regulated in the Act. But this is not following the Compliance of taxpayers themselves, there are still many taxpayers who are not aware of the importance of paying and reporting taxes. As the times are more advanced and so is taxation. taxation system also began to increasingly save time and energy, taxpayers in carrying out the administration of obligations tax.

According to the TAM theory developed by Davis, (1989), this theory explains information systems that make models of how users are willing to accept and use technology related to user tasks. According to the TAM theory, two belief variables encourage someone to want to use the system, namely: the perception of ease and the perception of usefulness, these two variables can explain to the user that the user's reason for seeing the benefits and ease of use of information technology causes the user's actions to accept the use of information technology, and will impact affects the interest to use it and forms an added value. Therefore this theory affects the behavior of individuals in the use of e-SPT, e-Invoice, e-Filing. The use of e-SPT, e-Invoicing, eFiling affects the Compliance of taxpayers, if the use of e-SPT, e-invoicing, e-Filing increases, it affects the behavior of taxpayers to behave obediently, so that taxpayer compliance also increased.

\section{THEORY OF COMPLIANCE}

According to the Indonesian General Dictionary, Compliance comes from the word obey, Obedient means love and obedience to orders or rules, and discipline. Compliance means submissive nature, obedient, subject to the doctrine or rules. According to Komalasari (2005) about Compliance, Compliance needs to be known first about what must be measured, whether evasion, avoidance, Compliance or noncompliance. The Compliance can be categorized into 2 terms: 
1. Administrative Compliance is a form of Compliance with administrative rules such as timely submission of payments.

2. Technical Compliance, taxpayer compliance with technical tax payments, for example, taxes, are calculated under the taxation law's technical provisions.

\section{HYPOTHESIS}

\section{The Effect of Implementation on E-SPT Taxpayer Compliance}

e-SPT is an application for creating electronic notification forms. e-SPT is made to replace paper form notification forms, the Application of this Application minimizes waste of paper usage. So by applying e-SPT it can make it easier for taxpayers to calculate and report the amount of tax that must be paid following applicable laws, to increase taxpayer compliance.

Research conducted by Harish (2014) states that e-SPT has a positive effect on taxpayer compliance. Research conducted by Indrianti (2017) states that e-SPT has a positive impact on tax compliance. Based on the description above, the following research hypotheses are prepared:

$\mathrm{H}_{1} \mathrm{H}_{2}$ : The Application of e-SPT has a positive effect on taxpayer compliance.

\section{Effect of Application on E-Invoice Taxpayer Compliance}

e-Invoice is an application to make electronic tax invoices or proof of VAT collection electronically. The application e-Invoice can make it easier for taxpayers to make tax invoices without having come to the Tax Service Office (KPP), in addition to the use of electronic applications can also reduce paper costs so that it is environmentally friendly, and the use of applications e-invoice can also minimize the existence of invoices false. So that the Application of e-invoices can affect the Compliance of taxpayers.

Amelia's research (2016) states that the Application of e-Invoices has a positive effect on tax compliance. Research conducted by Husnurrosyidah (2017) states that einvoicing has a positive effect on tax compliance. Based on the description above, then compiled the following research hypothesis:

$\mathrm{H}_{2}$ : Application of e-invoicing has a positive effect on tax compliance.

\section{The Effect of Implementation E-Filing on Taxpayer Compliance}

This is one of the SPT reporting in electronic form which is done on the website DGT online. the purpose for which it is applied e-filing, which is to facilitate taxpayers in reporting tax returns (SPT). so, applying e-filing can help taxpayers to fulfill their obligations quickly and accurately to increase compliance taxpayers. Research conducted by Havid (2014) states that the Application of e-filing has a positive influence on taxpayer compliance. Research conducted by Nurhidayah (2015) states that the adoption of the e-filing system has a positive effect on taxpayer compliance. Based on the description above, the research hypothesis is prepared as follows: 
$\mathrm{H}_{3}$ : The Application of e-filing has a positive effect on taxpayer compliance.

\section{RESEARCH METHODOLOGY}

This research was conducted at the East Denpasar Pratama Tax Office located at Jalan Captain Tantular No. 4 GKN II, Denpasar, Bali. The object of study in this study is the Application of e-Spt, e-Invoice, and e-Filing Against Taxpayer Compliance in the 2018 tax year at the East Denpasar Pratama Tax Office. The variables used in this study are: Dependent variable (dependent variable) is a variable that is affected or becomes or becomes a result, because of the independent variables (Sugiyono, 2017: 68). The variable dependent in this study is taxpayer compliance $(\mathrm{Y})$ in the KPP Pratama Timur Denpasar 2018 period. The independent variable is the variable that influences or causes the change or emergence of the dependent variable (Sugiyono, 2017: 68). Independent variables in this study include the Application of e-SPT (X1), Application of e-Invoicing (X2), and Application of e-Filing (X3) in the East Denpasar Pratama Tax Office 2018 period.

The types of data used in this study were divided into 2 (two), namely: qualitative and quantitative data. Quantitative data is data in the form of numbers or qualitative data that is leveraged (Sugiyono, 2017: 14). Quantitative data used in this study are answers to the questionnaire questions that have been quantified, the number of taxable entrepreneurs in East Denpasar KPP. Quantitative Data is data stated in the form of words, sentences, schematics, and pictures (Sugiyono, 2017: 15). Qualitative data used in this study is a list of questions or questions listed in the questionnaire, an overview of the company, organizational structure, and company activities. The data source used in this study can be divided into 2 (two), namely: primary data sources and secondary data sources. Primary data sources are data directly obtained from research objects. The sources taken in this study as primary data are taxable entrepreneurs who are registered at KPP Pratama Timur Denpasar. Secondary data is a source that does not indirectly provide data to data collectors, for example through other people or documents (Sugiyono, 2017: 137). Secondary data from this study are data obtained from East Denpasar KPP such as the number of entrepreneurs subject to Tax and the number of levels of Compliance.

The population in this study were all taxpayers at the Taxable Entrepreneur Entity who were registered at the East Denpasar KPP Pratama. The sampling method used in this study uses Non-Probability Sampling, a method which is the method Incidental Sampling. Incidental sampling is a technique of determining samples based on chance, i.e. anyone who accidentally meets with a researcher can be used as a sample if it is deemed that the person who happened to be met is suitable as a source of data (Sugiyono, 2017: 85). Determination of the sample after calculated with the Slovin formula (Umar, 2014: 78), which is 100.

The data collection method used in this study is the questionnaire method (Questionnaire). The questionnaire method is a data collection technique that is done 
by giving a set of questions or written statements to respondents to be answered (Sugiyono, 2017: 225). The questionnaire was a list of questions regarding Taxpayer Compliance, e-SPT, e-Invoice, and e-Filing which would then be given to respondents. Respondents 'answers given in the range of 1 to 5 are used in this study with the reason to avoid respondents' ambiguous answers due to doubtful or neutral statements.

The analysis technique used to solve the problem in this study is multiple linear regression. This analysis technique is used to determine the dependence of one dependent variable with one or more independent variables.

\section{RESULTS AND DISCUSSION}

\section{RESUlTS OF MULTIPLE LINEAR REGRESSION ANALYSIS}

In the multiple linear regression model, the dependent variable is taxpayer compliance while the independent variable is the Application of e-SPT, Application of e-Invoicing, and Application of e-Filing. The results of multiple linear regression analysis obtained from processing can be seen in the following table 2 :

Table 2. Results of Multiple Linear Regression Analysis

\begin{tabular}{|c|c|c|c|c|c|c|}
\hline \multirow{2}{*}{\multicolumn{2}{|c|}{ Model }} & \multicolumn{2}{|c|}{ Unstandardized Coefficients } & \multirow{2}{*}{$\begin{array}{l}\text { Standardized Coefficients } \\
\text { Beat }\end{array}$} & \multirow{2}{*}{$\mathbf{t}$} & \multirow{2}{*}{ Sig } \\
\hline & & B & Std. Error & & & \\
\hline \multirow[t]{4}{*}{1} & (Constant) & -3.554 & 1.311 & & -2.711 & .008 \\
\hline & PS & .293 & .059 & .314 & 4.947 & .000 \\
\hline & PF & .321 & .078 & .289 & 4.090 & .000 \\
\hline & PFL & .409 & .067 & .451 & 6.139 & .000 \\
\hline
\end{tabular}

Based on Table 2 it can be concluded that the linear regression equation is as follows:

$$
\mathrm{KWP}=-3.554+0.293 \mathrm{PS}+0.321 \mathrm{PF}+0.409 \mathrm{PFL}
$$

The meaning of linear regression multiple can be explained as follows:

1. The constant-coefficient is -3.554 meaning that if the three variables of $e-S P T$ implementation, e-Invoice Application, and application e-Filing are constant then taxpayer compliance has a negative value of -3.554

2. Application of $e-S P T$ Value 0.293 means that if the Application of $e-S P T$ increased by 1 unit by 0.293 then tax compliance would increase by 0.293 units assuming other variables were constant.

3. The Application of e-Invoices Value of 0.321 means that if the Application of $e$ Invoices increases 1 unit by 0.321 , the taxpayer compliance will increase by 0.321 units assuming other variables are constant.

4. The Application of $e$-Filing value of 0.409 means that if the Application of $e$ Filing increases 1 unit by 0.409 , the taxpayer compliance will increase by 0.409 units assuming other variables are constant. 


\section{MODEL FEASIBILITY TEST (TEST GOODNESS OF FIT)}

\section{Test Results The coefficient of determination (R2).}

The coefficient of determination $\left(\mathrm{R}^{2}\right)$.in essence, measuring how far the model's ability to explain the variation of the dependent variable or in other words to test the goodness-fit of the regression model. Determination coefficient test results are shown in Table 3 below:

Table 3. The coefficient of determination $\left(\mathrm{R}^{2}\right)$

\begin{tabular}{lllll}
\hline Model & $\mathbf{R}$ & R Square & Adjusted R Square & Std. The error of the Estimate \\
\hline 1 & $0.811^{\mathrm{a}}$ & 0.658 & 0.647 & 1.40936 \\
\hline \multicolumn{5}{c}{ Source: data processed 2019 }
\end{tabular}

Based on table 3 we can find out the Adjust $\mathrm{R}^{2}$ value of 0.647 , which means the implementation variable e-SPT, e-Invoice Application, the Application is e-Filing able to clarify the Compliance bound variable taxpayers at $64.7 \%$, while the remaining $35.3 \%$ is influenced by other variables.

\section{F Statistical Test Results in The F}

the statistical test aims to determine the feasibility of multiple linear regression models as an analytical tool that tests the effect of independent variables on the dependent variable. If the significance value of ANOVA $\leq 0.05$, then this model is feasible or fit. The results of the determination coefficient test can be seen in the following table 4 :

Table 4. F-Statistical Test Results

\begin{tabular}{|c|c|c|c|c|c|}
\hline Model & Sum of Squares & $\mathrm{df}$ & Mean Square & $F$ & Sig \\
\hline 1 Regression & 366.307 & 3 & 122.102 & 61.473 & $.000^{\mathrm{a}}$ \\
\hline Residual & 190.6583 & 96 & 1.986 & & \\
\hline Total & 556.990 & 99 & & & \\
\hline
\end{tabular}

Based on Table 4 obtained a value of significance of 0,000 that is smaller than 0.05 . This means that there is an influence between the variables of e-SPT Implementation, $e$ Invoice Application, and Application e-Filing together affect the taxpayer compliance variable.

\section{Hypothesis Test Results (t-test)}

Hypothesis testing is done by t-test which is also referred to as an individual significant test (Ghozali, 2016: 99). This test shows how far the influence of individual independent variables on the dependent variable. The decision making criteria, namely if the value is significant 0.05 , the independent variable influences the dependent variable. If the significant value $>0.05$, then the independent variable does not affect the dependent variable. The T-test can be seen in Table 5. 
Table 5. T-Test Results

\begin{tabular}{lllllll}
\hline \multirow{2}{*}{ Model } & \multicolumn{2}{l}{ Unstandardized Coefficients } & Standardized Coefficients & \multirow{2}{*}{ t } & \multirow{2}{*}{ Sig } \\
\cline { 2 - 4 } & B & Std. Error & Beat & -2.711 & .008 \\
\hline 1 & (Constant) & -3.554 & 1.311 & & 4.947 & .000 \\
& PS & .293 & .059 & .314 & 4.090 & .000 \\
& PF & .321 & .078 & .289 & 6.139 & .000 \\
\hline
\end{tabular}

Source: data processed 2019

1. Hypothesis Testing 1 . For the variable e-SPT(PS) has a regression coefficient of 0.293 with a significance level of 0,000 . It can be concluded that the implementation of variable $e-S P T$ (PS) has a positive effect on tax compliance so that $\mathrm{H}_{1}$ is accepted.

2. Hypothesis Testing 2 . The variable $e$-Invoice $(\mathrm{PF})$ has a regression coefficient of 0.321 with a significance level of 0,000 . It can be concluded that the implementation of variables e-Invoicing (PF) has a positive effect on tax compliance so that $\mathrm{H}_{2}$ is received.

3. Hypothesis Testing 3. For the Application variable, e-Filing (PFL) the regression coefficient is 0.409 with a significance level of 0,000 . It can be concluded that the implementation of variable e-Filing (PFL) has a positive effect on tax compliance so that $\mathrm{H}_{3}$ accepted.

\section{DISCUSSION OF RESEARCH RESULTS}

\section{THE EFFECT OF APPLICATION OF E-SPTON TAXPAYER COMPLIANCE}

Based on the results of the study showed that the significance of the one-sided t-test for the e-SPT implementation variable was 0,000 , the level significance was 0,000 greater than $=0.05$ and the regression coefficient value of 0.293 this indicates that the Application of $e-S P T$ has a positive effect on taxpayer compliance at the East Denpasar Pratama Tax Office so that the first hypothesis is accepted. In this case, it means that by applying e-SPT taxpayers will be easier in tax reporting so that taxation can be well organized and systematic. Tax calculations can also be done quickly and accurately, making it easier for taxpayers at the East Denpasar Tax Service Office to fulfill their tax obligations. The taxation data will be automatically saved in the database $e-S P T$. The ease felt by taxpayers in the presence of $e-S P T$ also minimizes the number of human resources in the calculation and recording of taxation data to cause a sense of satisfaction felt by taxpayers. Thus the better the Application of the system e-SPT, the Compliance of taxpayers will increase. The results of this study are in line with research by Indrianti (2017), and Harish (2014) that the Application of e-SPT has a positive effect on tax compliance.

\section{THE EFFECT OF APPLICATION E-INVOICING ON TAXPAYER COMPLIANCE}

Based on the results of the study showed that the significance of a one-sided $t$-test for the application variable $e$-Invoicing was 0,000 , the level significance of $t$ was 0,000 less 
than $=0.05$ and the regression coefficient value was 0.321 . indicates that the Application of e-Invoices has a positive effect on taxpayer compliance at the East Denpasar Pratama Tax Office so that the second hypothesis is accepted. In this case, it means that the application of e-Invoicing can make it easier for taxpayers to make tax invoices without having to come to the Tax Service Office (KPP), in addition to the use of the application e-Invoicing it can also reduce paper costs so that it is environmentally friendly. Tax calculations can also be done quickly and precisely, making it easier for East Denpasar KPP Taxpayers to fulfill their tax obligations. The data stored in the application e-Invoicing is also always complete because the taxation data will be stored automatically in the database e-Invoice. Thus the better the Application of the system e-Invoicing, the Compliance of taxpayers will also increase. This study is in line with the study of Indrianti (2017), and Mujiyati (2018) that the Application of $e$-Invoicing has a positive effect on taxpayer compliance.

\section{THE EFFECT OF APPLICATION E-FILINGON TAXPAYER COMPLIANCE}

Based on the results of the study showed that the value significance of one-sided t-test for the implementation variable $e$-Filing was 0,000 , the level significance of $t$ was 0,000 less than $=0.05$, and the regression coefficient value of 0.409 this case indicates that the Application of $e$-Filing has a positive effect on taxpayer compliance at the East Denpasar Pratama Tax Office so that the third hypothesis is accepted. In this case, it means that by implementing e-Filing it is easy to submit tax returns online and in realtime through the website of the Directorate General of Taxes or taxpayers can submit tax returns through application service companies (ASPs) that have been designated by the DGT. According to Mujiyati (2018), the Application of e-Filing can also overcome several problems faced by the DGT. These problems include, among other things, a large administrative burden for DGT in receiving, managing, and filing tax returns throughout the year. With the e-Filing system created by the Directorate General of Taxes, it can aim to improve services to taxpayers and is expected to improve taxpayer compliance in the reporting of Notification. So, applying e-Filing can help taxpayers to fulfill their obligations quickly and accurately to increase taxpayer compliance. Thus the better the Application of the system e-Filing, the Compliance of taxpayers will increase. This research is in line with research by Agustiningsih (2016), Indrianti (2017), and Mujiyati (2018) which proves that the Application of $e$-Filing has a positive effect on tax compliance.

\section{CONCLUSIONS}

\section{CONCLUSIONS}

Based on the results of the analysis and descriptions in the previous chapter regarding the Application of $e$-System that affects taxpayer compliance by using independent variables e-SPTimplementation, e-Invoice Application, and application $e$-Filing can be concluded as follows: 
1. Application of $e-S P T$ has a positive effect on taxpayer compliance at the East Denpasar Pratama Tax Office. Thus the better the Application of the system $e$ $S P T$, the taxpayer compliance will also increase.

2. The Application of e-Invoices has a positive effect on taxpayer compliance at the East Denpasar Pratama Tax Office. Thus the better the Application of the system e-Invoice, the taxpayer compliance will increasingly increase

3. The adoption of $e$-Filing has a positive effect on taxpayer compliance at the East Denpasar Pratama Tax Office. Thus the better the Application of the system $e$ Filing, the taxpayer compliance will increase.

\section{SUGGESTIONS}

Based on the results of the research that has been done, some suggestions can be made as follows:

1. The East Denpasar Primary Tax Office is expected to continue to increase the level of taxpayer adoption in using e-system services through IT innovations so that taxpayers will experience real benefits.

2. East Denpasar Primary Tax Service Office Occasionally training on how to use can be conducted can be done e-System, and it is hoped that the socialization of procedures for using e-System through the tax office, especially for beginners. This is so that taxpayers do not think that the e-System is difficult, by socializing it through advertisements, taxpayers have the desire to try using the e-System in SPT reporting.

3. For further researchers, it is hoped that they can observe other factors that can affect taxpayer compliance in tax reporting such as the Application of $e$-Billing, $e-N o f a$ which can affect a person's Compliance in reporting the Tax Return.

4. For further researchers, it is better to increase the number of samples in the study, for example, not only PKP taxpayers but all PKP and non-PKP taxpayers so that the data generated by further researchers is more accurate.

\section{Reference:}

Agustiningsih. 2016. The Effect of Application E-Filing, Tax Understanding Level, and Taxpayer Awareness of Taxpayer Compliance at KPP Pratama Yogyakarta. Taxation Journal, Vol. V No. 2. pp 107-102.

Davis, F. D. (1989). Perceived usefulness, perceived ease of use, and user acceptance of information technology. MIS quarterly, 319-340.

Ghozali, Imam. 2016. Multivariate Analysis Application with the IBM SPSS 23 program. Semarang: Diponegoro University Publishing Agency.

Husnurrosyidah, Suhadi. 2017. The Effect of e-Filing, e-Billing, and e-Invoice on Tax Compliance at BMTs in Kudus Regency. Journal of Accounting and Taxation Analysis. Volume 1 No. 1

Harish, M. 2014. The Effect of Implementation on e-SPTTaxpayer Compliance (Survey at the Primary Tax Service Office. Taxation Journal. Accounting Department at the Faculty of Economics, Widyatama University Bandung. 
Havid, M. 2014. The Effect of Application on e-Filing Compliance Levels Taxpayers (Survey Study at the Bandung Cibeunying Tax Office). Thesis. Faculty of Economics, Widyatama University Bandung.

Indrianti, I, Suhendro, and Masitoh E. 2017. The Effect of Implementation e-System Taxationon Corporate Taxpayer Compliance (Case Study at KPP Pratama Surakarta). Journal of Taxation, IENACO-2017, ISSN: 2337-4349. Department of Accounting, Faculty of Economics, Islamic University of Batik Surakarta.

Komalasari, R. (2005). Buku Ajar Fundamental Keperawatan: Konsep. Proses, dan Praktik, Jakarta, EGC.

Maryani. 2019. The Influence of Taxpayer Behavior on Taxpayer Compliance With the use of e-Filing as an Intervening Variable at KPP Pratama Gianyar. Journal of Accounting and Management Science, Vol. 1, No. 2. Department of Accounting, Faculty of Economics, Mahasaraswati University Denpasar .

Mujiyati, and Abdurahman YA. 2018. The Effect of Implementation on e-System Taxation Taxpayer Compliance (Empirical Study of Corporate Taxable Entrepreneurs Registered at KPP Pratama Karanganyar) Thesis. Department of Accounting, Faculty of Economics and Business, Muhammadiyah University, Surakarta.

Nurhidayah. 2015. The Implementation on e-Filing Effect of Taxpayer Compliance with Internet Understanding as a Moderating Variable at KPP Pratama Klaten. Essay. Accounting Study Program, Faculty of Economics, Yogyakarta State University.

Prabawa, M. A. M., \& Noviari, N. (2012). Pengaruh Kualitas Pelayanan Dan Sikap Terhadap Kepatuhan Pelaporan Wajib Pajak Orang Pribadi di KPP Badung Utara. E-Jurnal Akuntansi Universitas Udayana, 1, 1-11.

Sugiyono. 2017. Business Research Methods. Bandung: Alfabeta.

Suherman, M, and Medina AL. 2016. The Effect of Implementation on e-Filing Taxpayer Compliance in Submitting Annual Tax Returns (SPT) at the Tasikmalaya City Primary Tax Service Office. Journal of Accounting Research, Auditing \& Information, Vol. 15, No. 1. Faculty of Economics, University of Siliwangi, Tasikmalaya.

Umar, Husein. 2014. Research Methods for Thesis and Business Thesis. Jakarta: National Library: Catalog in Publications (KDT) 